\title{
E O ANO COMEÇA SEM A APROVAÇÃO DO ORÇAMENTO FEDERAL
}

Coluna publicada em 15.1.2013: <http://www.conjur.com.br/2013-jan-15/ contas-vista-ano-comeca-aprovacao-orcamento-federal $>$

Estamos em 2013, com as esperanças sempre renovadas de um ano melhor e as expectativas otimistas, como deve ser. Mas há que se reconhecer não ter o ano começado muito bem para o Direito Financeiro.

Além da não desejada, mas de certa forma esperada, falta de aprovação dos critérios de rateio do FPE (vide coluna de 23 de outubro de 2012, Reformular o FPE para adequar o federalismo fiscal), que já fez o governo federal começar o ano com uma grave inconstitucionalidade, desobedecendo acórdão do Supremo Tribunal Federal, acrescenta-se que o orçamento federal não foi aprovado.

A lei orçamentária é, depois da Constituição, a mais importante para o país, como já disse o ministro Ayres Britto (ADI-MC 4.048-1/DF, j. 14.5.2008, p. 38), e é a base de todo o sistema orçamentário. No Brasil, é lei anual, correspondendo o exercício financeiro ao ano civil, de $1^{\circ}$ de janeiro a 31 de dezembro, como determina a Lei 4.320/1964, artigo 34. Deve, portanto, ser renovada tempestivamente, sob pena de gerar graves consequências para o país, para a administração pública e para os gestores públicos. O princípio da legalidade, no âmbito do Direito Financeiro, exige que toda despesa seja autorizada por lei, e a lei orçamentária é fundamental para cumprir esse papel.

Ocorre que nem sempre se consegue aprovar o orçamento até o final do ano, gerando a situação de "anomia orçamentária", iniciando-se o exercício financeiro seguinte sem orçamento e, consequentemente, sem autorização para efetuar os gastos públicos, paralisando a administração. 
A situação não é nova e, no âmbito federal, já houve casos bastante graves, como ocorreu em 1994, em que a lei orçamentária, que deveria ter sido aprovada até o final de 1993, só veio a sê-lo em novembro de $1994 !^{1}$

Várias são as possibilidades de resolver a questão da falta de orçamento, que, registre-se, pode ocorrer por diversas razões além da não aprovação tempestiva: não apresentação do projeto de lei, rejeição do projeto de lei, veto, etc. A doutrina já se debruçou sobre o tema, defendendo as mais diversas teses: prorrogação do orçamento vigente, aprovação do projeto por decurso de prazo, abertura de créditos orçamentários específicos ou a regulamentação prévia da situação pela Constituição ou pela lei.

O Brasil já adotou, e continua adotando, a última hipótese, qual seja, estabelecendo normas admitindo essa possibilidade e regulamentando a situação. As Constituições de 1946 e 1967 previram a aprovação do projeto de lei orçamentária por decurso de prazo (arts. 74 e 68, respectivamente). ${ }^{2}$ A Constituição de 1988 é omissa nesse aspecto e, atualmente, a situação vem sendo regulada, no âmbito federal, por dispositivos reiterados nas Leis de Diretrizes Orçamentárias que, usualmente, contemplam autorizações para a execução provisória do projeto de lei orçamentária dentro dos limites fixados, em geral 1/12 da dotação prevista para cada mês. Com isso, evita-se a paralisação da administração enquanto não aprovada a lei orçamentária.

É o que está previsto, por exemplo, na LDO da União para 2013, ${ }^{3}$ artigo 50, que enumera taxativamente as despesas que poderão ser executadas.

Trata-se, no entanto, de medida de caráter provisório e limitado, uma vez que não dá liberdade ao gestor para todos os gastos, sendo tão somente um paliativo enquanto não se consegue a aprovação do orçamento, cuja demora causa evidentes prejuízos a toda a população. E isso sem contar o caráter pouco democrático da qual se reveste, uma vez que se coloca em execução, sem ter passado pelo crivo do Poder Legislativo, essa lei tão importante.

No ano de 2007, ao se encerrar o exercício financeiro sem a aprovação da lei orçamentária federal para 2008, foi baixada a Medida Provisória 405, de 18 de dezembro de 2007 (posteriormente convertida na Lei 11.658), abrindo créditos extraordinários no valor global de praticamente $\mathrm{R} \$ 5,5$ bilhões para grande parte

Lei 8.933, de 9 de novembro de 1994.

2 Veja-se com um pouco mais de detalhes em CONTI, José Mauricio (coord.), Orçamentos públicos - a Lei 4.320/1964 comentada, 3. ed., São Paulo: RT, 2014, p. 127-129.

3 Lei 12.708, de 17 de agosto de 2012. 
da administração pública federal. Significou, basicamente, uma antecipação do orçamento, feita por Medida Provisória, instrumento jurídico inadequado para isto, em face de expressa disposição constitucional (CF, art. $62, \mathbb{\$} 1^{\mathrm{o}}, d$ ), cabível somente para situações que importassem em despesas imprevisíveis e urgentes, decorrentes de guerra, comoção interna ou calamidade pública (CF, art. 167, $\$ 3^{\circ}$ ).

A norma foi objeto de ação declaratória de inconstitucionalidade junto ao Supremo Tribunal Federal (ADI-MC 4.048-1/DF, rel. Min. Gilmar Mendes, j. 14.5.2008), que, em decisão paradigmática, mudando a orientação até então vigente naquela Corte, determinou a suspensão da sua vigência, uma vez que não estavam presentes os requisitos constitucionalmente exigidos, a saber, a imprevisibilidade e a urgência, mesmo porque não se estava em situação de guerra, comoção interna ou calamidade pública. Como bem posto na decisão, “(...) 'guerra', 'comoção interna' ou 'calamidade pública' são conceitos que representam realidades ou situaçóes fáticas de extrema gravidade e de consequências imprevisíveis para a ordem pública e a paz social, e que dessa forma requerem, com a devida urgência, a adoção de medidas singulares e extraordinárias. A leitura atenta e a análise interpretativa do texto e da exposição de motivos da MP 405/2007 demonstram que os créditos abertos são destinados a prover despesas correntes, que não estão qualificadas pela imprevisibilidade ou pela urgência. A edição da MP 405/2007 configurou um patente desvirtuamento dos parâmetros constitucionais que permitem a edição de medidas provisórias para a abertura de créditos extraordinários".

Ou seja, nossa Suprema Corte, de forma clara e inequívoca, reconheceu não ser cabível, em face do ordenamento jurídico vigente, a edição de medidas provisórias abrindo créditos extraordinários para "antecipar o orçamento", em virtude de sua não aprovação tempestiva, autorizando despesas que não são imprevisíveis e urgentes, e fora do contexto de guerra, comoção interna ou calamidade pública.

Muito bem.

E o que vemos no apagar das luzes de 2012?

A Medida Provisória 598, de 27 de dezembro de 2012, abrindo créditos extraordinários no montante de R \$ 47 bilhōes para os Orçamentos Fiscal e da Seguridade Social!

Não me consta que o Brasil tenha declarado guerra recentemente, desconheço qualquer comoção interna ou calamidade pública ocorrida na última semana de dezembro que justifique a medida. A única calamidade pública visível é a jurídica, com a edição dessa medida provisória!

E se alguém pensa que, na extensa lista de rubricas orçamentárias beneficiadas pelos créditos extraordinários estão contempladas despesas imprevisíveis e urgentes, 
basta abrir o anexo I, e a primeira dotação que vai encontrar é de $\mathrm{R} \$ 10$ milhões para "comunicação e divulgação institucional da Câmara dos Deputados"! E por aí vai...

É por demais flagrante o desrespeito à Constituição e à decisão do Supremo Tribunal Federal.

O Direito Financeiro tem sido pródigo em exemplos de afronta à Constituição e ao ordenamento jurídico como um todo.

Mas começar o ano "dando de ombros" à decisão que estabeleceu o prazo máximo de vigência dos critérios de rateio do Fundo de Participação dos Municípios para o dia 31 de dezembro de 2012, continuando a cumprir lei já declarada inconstitucional como se nada tivesse acontecido, e agora "completar a obra" editando medida provisória em situação absolutamente idêntica à que já foi reconhecida como indevida pela nossa Suprema Corte, é ultrapassar todos os limites.

Já passou a hora de se exigir e cobrar um mínimo de respeito à Constituição e à nossa Suprema Corte.

O Direito Financeiro não merece isso. Aliás, o Direito não merece. Melhor dizendo, ninguém merece... 